\title{
PENGARUH KONSENTRASI NAOH TERHADAP RENDEMEN $\beta$-NAFTOL PADA PROSES PEMBUATAN $\beta$-NAFTOL
}

\author{
Irfan Purnawan ${ }^{1)}$, Sugono ${ }^{1)}$ \\ 1)Jurusan Teknik Kimia Fakultas Teknik Universitas Muhammadiyah Jakarta \\ irfan.purnawan@umj.ac.id
}

\begin{abstract}
Color has an important role in the appeal of a product, so that the use of dyes both natural and synthetic become a necessity that can not be avoided. $\beta$-naphtol is a synthetic dye used as a coloring agent clothing. This study aims to find the influence of the concentration of sodium hydroxide to yield $\beta$-naphtol. The method used in this research is the method of sulfonation. Naphthalene reacted with H2SO4 and heated to a temperature of $170 \circ \mathrm{C}$ and soda ash is added to maintain the temperature and allowed to stand until they reach room temperature. Then added a solution of lime and filtered. The filtrate is naphthalene sodium sulfate crystals are then added a solution of $\mathrm{NaOH}$, heated to a temperature of $3000 \mathrm{C}$ and cooled to room temperature. Further diluted with hot water and thick drops of concentrated $\mathrm{HCl}$ excess, it will form crystals precipitate $\beta$-naphtol can be weighed. The result is the best concentration of $1.25 \mathrm{~mol} \mathrm{NaOH}$ by the equation $y=9,9737 \mathrm{X}$ +81.905 and $R 2=0.8519$. The conclusion was that the higher concentration of $\mathrm{NaOH}$, giving a yield of $\beta$-naphtol were higher as well to a concentration of $1.25 \mathrm{~mol}$. However, after the concentration of $\mathrm{NaOH}$ was increased to $1.5 \mathrm{~mol}$, the yield decreased.
\end{abstract}

Keywords: naphtol, yield, natural dyes, synthetic

ABSTRAK. Warna memiliki peran penting dalam memberikan daya tarik terhadap suatu produk, sehingga penggunaan zat pewarna baik yang alami maupun sintesis menjadi kebutuhan yang tidak dapat dihindarkan. $\beta$-naphtol merupakan salah satu zat pewarna sintesis yang biasa digunakan sebagai zat pewarna pakaian. Penelitian ini bertujuan untuk mencari pengaruh konsentrasi Natrium Hidroksida terhadap rendemen $\beta$-naphtol. Metode yang digunakan dalam penelitian ini adalah metode sulfonasi. Naftalen direaksikan dengan $\mathrm{H}_{2} \mathrm{SO}_{4}$ dan dipanaskan hingga suhu $170^{\circ} \mathrm{C}$, lalu ditambahkan soda abu dengan mempertahankan suhunya dan didiamkan hingga tercapai suhu ruangan. Kemudian ditambahkan larutan lime dan disaring. Filtrat merupakan kristal sodium naftalena sulfat yang selanjutnya ditambahkan larutan $\mathrm{NaOH}$, dipanaskan hingga suhu $300^{\circ} \mathrm{C}$ dan didinginkan hingga suhu ruangan. Selanjutnya diencerkan dengan air panas dan diteteskan $\mathrm{HCl}$ pekat berlebih, maka akan terbentuk endapan kristal $\beta$-naphtol yang dapat ditimbang beratnya. Hasil penelitian didapat konsentrasi $\mathrm{NaOH}$ terbaik yaitu 1,25 mol dengan persamaan $y=$ $9,9737 X+81,905$ dan $R^{2}=0,8519$. Kesimpulan yang didapat adalah semakin tinggi konsentrasi $\mathrm{NaOH}$, memberikan rendemen $\beta$-naphtol yang semakin tinggi juga hingga konsentrasi sebesar 1,25 mol. Namun setelah konsentrasi $\mathrm{NaOH}$ dinaikan ke 1,5 mol, rendemen mengalami penurunan.

Kata kunci: naphtol, rendemen, pewarna alami, sintesis 


\section{PENDAHULUAN}

Dengan berkembangnya teknologi pada saat ini sehingga persaingan untuk menjadi yang terbaik di dalam melakukan usaha maka perlu dilakukan inovasi dan kreasi untuk mencapai tujuan tersebut. Cara yang perlu dilakukan salah satunya adalah dengan menggunakan pewarnaan yang menarik untuk setiap produk yang akan dihasilkan sehingga menjadi daya tarik untuk para konsumen.

Pewarna yang biasa digunakan untuk mewarnai produk biasanya terdiri dari pewarna alami dan pewarna sintetis. Namun yang paling banyak digunakan adalah pewarna sisntetis karena mudah diperoleh, praktis penggunaan-nya dan relatif lebih murah/terjangkau harganya.

Saat ini telah banyak diproduksi pewarnapewarna sintetis yang terbuat dari berbagai macam zat kimia salah satunya adalah $\beta$ Naphtol. Sehingga perlu kiranya diteliti bagaimana cara memaksimalkan produksi $\beta$-Naphtol dari naphtalena dengan penambahan larutan $\mathrm{NaOH}$.

$\beta$-Naphtol dapat diproduksi dengan beberapa cara diantaranya dengan cara Sulfonisasi Naphtalena di dalam Asam Sulfat pada suhu $170{ }^{\circ} \mathrm{C}$.

Dengan reaksi sebagai berikut:

I. $\mathrm{C}_{10} \mathrm{H}_{8}+\mathrm{H}_{2} \mathrm{SO}_{4} \rightarrow \mathrm{C}_{10} \mathrm{H}_{7} \mathrm{SO}_{3} \mathrm{H}+\mathrm{H} 2 \mathrm{O}$

II. $\mathrm{C}_{10} \mathrm{H}_{7} \mathrm{SO}_{3} \mathrm{H}+\mathrm{Na}_{2} \mathrm{CO}_{3} \rightarrow \mathrm{C}_{10} \mathrm{H}_{7} \mathrm{SO}_{3} \mathrm{Na}+$ $\mathrm{HCO}_{3}+\mathrm{Na}$

III. $\mathrm{C}_{10} \mathrm{H}_{7} \mathrm{SO}_{3} \mathrm{Na}+\mathrm{NaOH} \rightarrow \mathrm{C}_{10} \mathrm{H}_{7} \mathrm{OH}+$ $\mathrm{Na}_{2} \mathrm{SO}_{3}$

Penelitian ini bertujuan untuk memperoleh $\beta$-naphtol yang dibuat dari Naphtalena dengan menggunakan serangkaian reaksi kimia seperti sulfonasi, pertukaran dan pemanasan guna mengetahui pengaruh variable konsentrasi Natrium Hidroksida terhadap rendemen $\beta$-naphtol dan mencari kondisi optimum konsentrasi Natrium Hidroksida terhadap rendemen $\beta$-naphtol.

Pada proses pembuatan $\beta$-naphtol yang berasal dari Naphtalena dengan menggunakan metode tersebut diatas, terdapat beberapa faktor yang mempengaruhi $\beta$-naphtol yang dihasilkan, diantaranya temperatur, konsentrasi $\mathrm{H}_{2} \mathrm{SO}_{4}$, Konsentrasi $\mathrm{NaOH}$, dan bahan penambah lain.

Pada penelitian ini Konsentrasi $\mathrm{NaOH}$ akan dibuat bervariasi mulai dari $0,25 \mathrm{~mol}$ sampai dengan 1,5 mol sedangkan variabel yang lain tetap.

Manusia zaman prasejarah telah melakukan pewarnaan pada bulu-bulu binatang dan tekstil dengan menggunakam pewarna alami yang diambil dan tumbuhtumbuhan dan binatang liar. Di Mesir terdapat tulisan dan gambar-gambar yang telah diberi warna, dimana warna ini telah diambil dan ekstrax tumbuhan alami. Seperti halnya membuktikan bahwa gambar yang terdapat pada gua di Altainira menunjukan mereka telah menggunakan pewarna anorganik dimasa silam. Selama perkembangannya kurang lebih dan seratus tahun manusia telah menggunakan proses pewarna. Seperti contoh pada penduduk Asia mengambil ekstrax kelenjar siput ungu untuk mendapatkan warna ungu atau lembayung. Namun pada saat ini telah banyak digunakan warna buatan yang digunakan dalam industri tekstil (Ullmann's, 1994).

Semua jenis tekstil dapat diwarnai, yang perlu diperhatikan dalam hal ini adalah jenis formula yang dipakai harus disesuaikan dengan hasil akhir yang diinginkan. Zat warna basa dapat digolongkan pada garam-garam yang terdiri kation zat warna basa yang bermuatan positif dengan anion asam yang bermuatan negatif, zat warna basa mempunyai afinitas yang tidak luntur terhadap air (Ullmann's, 1994).

Kelarutan zat warna basa (Ullmann's, 1994):

- Mudah larut dalam larutan asam, sehingga biasanya untuk membuat larutan kental zat warna basa digunakan asam asetat.

- Dapat larut dalam air panas.

- Menggunakan air yang mempunyai kesadahan tinggi sejauh mungkin 
dihindari karena kalsium, magnesium dan karbonat akan menjadi masalah kalau jumlahnya lebih dari 50 ppm.

\section{Pengukuran Warna}

Faktor yang menentukan mutu bahan makanan diantaranya bergantung pada warna, cita rasa, tekstur dan nilai gizinya. Kolorimeter dan spektrofotometer adalah alat yang digunakan untuk mengukur warna suatu bahan. Tetapi alat - alat tersebut memiliki keterbatasan penggunaan untuk bahan dengan fase cair seperti warna hasil ekstraksi, bir atau sari buah. Warna dari bahan selain padatan atau cairan pengukurannya dilakukan dengan suatu warna standar yang ditunjukkan dalam angka - angka.

Besaran chroma, hue dan value adalah cara mengukur komponen warna yang lebih teliti. Intensitas warna ditunjukkan dengan nilai chroma. Warna merah, hijau atau kuning nilai hue yang menunjukkan panjang gelombang yang dominan. Intesitas warna ditunjukkan dalam nilai chroma. Kromatisitas permukaan bahan diukur dengan menggunakan alat khusus dari ketiga komponen tersebut.

Angka-angka yang diperoleh berbeda untuk setiap warna, dalam diagram kromatisitas angka - angka tersebut selanjutnya diplotkan (Winarno, 1997).

Ada lima hal yang menyebabkan suatu bahan makanan berwarna yaitu:

1. Pigmen yang secara alami terdapat pada tanaman dan hewan misalnya kiorofil berwarna hijau, karoten berwarna jingga, dan mioglobin menyebabkan warna merah pada daging.

2. Reaksi karamelisasi yang timbul bila gula dipanaskan membentuk warna coklat, misalnya warna coklat pada kembang gula karamel atau roti yang dibakar.

3. Warna gelap yang timbul karena adanya reaksi Maillard, yaitu antara gugus amino protein dengan gugus karbonil gula pereduksi; misalnya susu bubuk yang disimpan lama akan berwarna gelap.
4. Reaksi antara senyawa organik dengan udara akan menghasilkan warna hitam, atau coklat gelap. Reaksi oksidasi ini dipercepat oleh adanya logam serta enzim; misalnya warna gelap permukaan apel atau kentang yang dipotong.

5. Penambahan zat warna, baik zat warna alami maupun zat warna sintetik, yang termasuk dalam golongan bahan aditif makanan (Winarno,1997).

\section{Zat Pewarna}

Karena masih lemahnya sistem perundangan di Indonesia maka banyak celah yang digunakan untuk menyalahgunakan penggunaan zat pewarna, misalnya untuk mewarnai bahan makanan digunakan zat pewarna untuk tekstil atau pewarna kulit.

Seperti yang terjadi di Jakarta, Balai Besar Pengawasan Obat dan Makanan (BPOM) menemukan kandungan methanil yellow, zat pewarna sintetis yang seharusnya difungsikan untuk pewarna tekstil terdapat didalam puding yang dijual dikantin sekolah. Penemuan ini berkat inisiatif dari seorang siswa SD yang menyerahkan puding kepada petugas setelah merasakan adanya rasa pahit pada puding yang baru dibelinya. Mengkonsumsi methanil yellow secara terus menerus dapat mengakibatkan beberapa penyakit, termasuk, kerusakan pada hati (Romadoni, 2015).

Residu logam berat yang terdapat dalam zat warna tersebut jelas sangat mengancam bagi kesehatan manusia. Penyebab munculnya penyimpangan atau penyalahgunaan zat pewarna tersebut ditimbulkan karena kurangnya pengetahuan masyarakat tentang zat pewarna dan minimnya penjelasan mengenai zat pewarna seperti tabel berikut: 
Tabel 1. Zat pewarna bagi makanan dan minuman yang diijinkan di Indonesia

\begin{tabular}{clc}
\hline $\begin{array}{c}\text { Zat } \\
\text { Pewarna }\end{array}$ & \multicolumn{1}{c}{ Nama } & $\begin{array}{c}\text { Nomor Indeks } \\
\text { Warna }\end{array}$ \\
\hline Alami & Alkanat & 75520 \\
Merah & Karoten & 75130 \\
Kuning & Klorofil & 75810 \\
Hijau & Ultramarin & 77077 \\
Biru & Carbon & 77266 \\
Hitam & Black & 77891 \\
Putih & Titanium & 16185 \\
Sintesis & Oksida & 15985 \\
Merah & Oran & 19140 \\
Oranye & Amaranth & \\
Kuning & Sunsetyellow & \\
& Tartrazine & \\
\hline
\end{tabular}

Sumber: Direktorat Pengawasan Makanan dan Minuman (1998)

Pada saat ini aturan penggunaan zat pewarna di Indonesia diatur dalam SK Menteri Kesehatan RI tanggal 22 Oktober 1973 No. 11332/A/SK/73. Meskipun telah diatur, masih banyak terjadi penyimpangan dalam penggunaan zat pewarna; misalnya zat pewarna tekstil dipakai untuk mewarnai bahan makanan.

Hal ini disebabkan karena harga bea masuk zat pewarna untuk industri jauh lebih murah dibandingkan zat pewarna untuk bahan makanan.

Prosedur pengujian terhadap suatu zat pewarna sintetik diterapkan secara ketat di negara - negara maju. Permitted color atau certified colour adalah zat pewarna yang diijinkan penggunaannya dalam pewarna makanan.

Zat warna harus melalui proses sertifikasi dengan melewati prosedur dan test penggunaannya. Pengujian kimia adalah tahap dalam proses sertifikasi. Zat pewarna sintetik umumnya melalui tahapan pemberian asam sulfat atau asam nitrat yang sering terkontaminasi oleh logam logam berat seperti arsen yang besifat racun.

Proses pembuatan zat pewarna organik umumnya melalui proses yang seringkali meninggalkan hasil akhir yang berbahaya karna dalam proses tersebut melalui senyawa antara. Untuk zat pewarna yang dianggap aman, ditetapkan bahwa kandungan arsen tidak lebih dan 0,00014\% dan timbal tidak lebih dari $0,001 \%$.

Pada tahun 1906, Amerika serikat mengeuarkan peraturan tentang tujuh jenis zat pewarna yang diizinkan untuk dapat digunakan pada bahan makanan, peraturan tersebut dikenal dengan Food and Drug Act. (orange no 1, erythrosin, ponceau $3 R$, amaranth, indigotine, naphtolyellow dan light green).

Pada tahun 1938 di Amerika dikeluarkan peraturan baru yaitu Food, Drug and cosmetic Act (FD \& C) yang memperluas ruang lingkup peraturan tahun 1906 dalam mengatur penggunaan zat pewarna. Zat pewarna dapat digolongkan atas tiga kategori, yaitu FD \& C Color, $D \& C$ Color dan Ext $D \& C$ (Winarno, 1997).

FD \& C Color adalah zat pewarna yang diijinkan untuk makanan, obat-obatan dan kosmetik. D \& C Color diijinkan penggunaannya dalam obat-obatan dan kosmetik, sedangkan untuk bahan makanan dilarang. Ext D \& C Color diijinkan dalam jumlah terbatas pada obatobatan luar dan kosmetik.

Color Additive Amandement adalah peraturan tentang penggunaan zat pewarna yang dijadikan undang - undang dan dikeluarkan pada tahun 1960. Perubahan aturan menjadi undang undang ini terdiri dari pembagian zat pewarna menjadi dua kelompok yaitu certified dan uncertified color. Certified color adalah zat pewarna sintetik yang terdiri dari dye dan lake, sementara itu uncertified color adalah zat pewarna alami.

\section{a. Certified Color}

Certified Color terdiri dari dye dan lake. Dye adalah zat pewarna bersifat larut dalam air, propilenglikol, gliserol atau alkohol. Dye terdapat dalam bentuk bubuk, butiran, pasta, maupun cairan yang penggunaannya tergantung dan kondisi bahan, proses dan zat pewarnanya sendiri. 
FD \& C dye terbagi atas empat kelompok yaitu Azo dye, triphenyl methane, fluorescein dan sulfonated indigo. FD \& C lake diijinkan pemakaiannya sejak tahun 1959, dan penggunaannya meluas dengan cepat. Zat pewarna ini merupakan gabungan dari zat warna (dye) dengan radikal basa (Al atau $\mathrm{Ca}$ ) yang dilapisi dengan hidrat alumina atau $\mathrm{Al}(\mathrm{OH})_{3}$. Lapisan alumina atau $\mathrm{Al}(\mathrm{OH})$ ini tidak larut dalam air, sehingga lake ini tidak larut pada hampir semua pelarut. Lake stabil pada $\mathrm{pH}$ 3,5 - pH 9,5 (Winarno, 1997).

Sesuai dengan sifatnya yang tidak larut dalam air, zat pewarna ini digunakan untuk produk-produk yang tidak boleh terkena air, lake sering kali lebih baik digunakan untuk produk-produk yang mengandung lemak dan minyak dari pada dye, karena FD \& C dye tidak larut dalam lemak (Winarno, 1997).

Tabel 2. Perbedaan antara Dye dengan

\begin{tabular}{|c|c|c|}
\hline & Lake & \\
\hline Sifat & Lake & Dye \\
\hline Kelarutan & $\begin{array}{l}\text { Tak larut } \\
\text { dalam } \\
\text { sebaaian }\end{array}$ & $\begin{array}{l}\text { Larut } \\
\text { dalam air } \\
\text { propilen }\end{array}$ \\
\hline $\begin{array}{l}\text { Cara } \\
\text { mewarnai }\end{array}$ & $\begin{array}{l}\text { besar } \\
\text { pelarut }\end{array}$ & glikol, \\
\hline Pure dye & Dispersi & Terlarut \\
\hline content & $10-40 \%$ & $\begin{array}{l}\text { Warna } \\
\text { primer } 90\end{array}$ \\
\hline Ukuran & Rata-rata & $-93 \%$ \\
\hline partikel & 5 mikron & $\begin{array}{l}12-200 \\
\text { mesh }\end{array}$ \\
\hline Stabilitas & Cukup & \\
\hline terhadap: & Cukup & \\
\hline a. cahaya & & Baik \\
\hline b. panas & & Baik \\
\hline
\end{tabular}

Sumber: Noonan (1981)

\section{b. Uncertified Color Additive}

Zat pewarna yang termasuk dalam uncertified color ini adalah zat pewarna alami (Winarno, 1997). Zat pewarna ini bebas dan prosedur sertifikasi dan termasuk daftar yang telah ditetapkan. Uncertified color mempunyai batas maksimum pemakaian seperti terlihat pada tabel berikut ini.
Tabel 3. Batas Maksimum ADI untuk Uncertified Color

\begin{tabular}{lc}
\hline Zat pewarna & $\begin{array}{c}\text { ADI Maksimum } \\
(\mathbf{m g} / \mathbf{k g})\end{array}$ \\
\hline Annato & $125^{\mathrm{b}}$ \\
\hline Kantaxantin & $12,50^{\mathrm{a}}$ \\
\hline Kunyit (turmeric) & $0,50^{\mathrm{b}}$ \\
\hline Riboflavin & $0,50^{\mathrm{a}}$ \\
\hline
\end{tabular}

Sumber: Noonan (1981)

Keterangan:

$a=$ sudah bersifat tetap/mutlak, berdasarkan penelitian tentang sifat toksik dan metabolisme tubuh yang telah dilakukan.

$\mathrm{b}=$ Masih bersifat sementara, karena data tentang keamanannya belum lengkap

\section{Asam Sulfat, $\mathrm{H}_{2} \mathrm{SO}_{4}$}

Asam sulfat, $\mathrm{H}_{2} \mathrm{SO}_{4}$, merupakan asam mineral (anorganik) yang kuat. Zat ini larut dalam air pada semua perbandingan. Asam sulfat murni yang tidak diencerkan tidak dapat ditemukan secara alami di bumi oleh karena sifatnya yang higroskopis.

Walaupun asam sulfat yang mendekati $100 \%$ dapat dibuat, ia akan melepaskan $\mathrm{SO}_{3}$ pada titik didihnya dan menghasilkan asam $98,3 \%$. Asam sulfat $98 \%$ lebih stabil untuk disimpan, dan merupakan bentuk asam sulfat yang paling umum. Asam sulfat $98 \%$ umumnya disebut sebagai asam sulfat pekat.

Sifat-sifat asam sulfat yang korosif diperburuk oleh reaksi eksotermiknya dengan air. Luka bakar akibat asam sulfat berpotensi lebih buruk daripada luka bakar akibat asam kuat lainnya, hal ini dikarenakan adanya tambahan kerusakan jaringan dikarenakan dehidrasi dan kerusakan termal sekunder akibat pelepasan panas oleh reaksi asam sulfat dengan air.

\section{Kalsium Karbonat, $\mathrm{CaCO}_{3}$}

Kalsium Karbonat yang dimaksud adalah $\mathrm{CaCO}_{3}$ dalam bentuk tepung halus dengan standar produk yang telah ditetapkan oleh Departemen Perindustrian menurut ukuran butirannya calsium karbonate dibagi 
menjadi dua jenis yaitu: heavy grade dan light grade dan titik lelehnya $825^{\circ} \mathrm{C}$.

Menurut proses pembuatannya, bahan baku Kalsium Karbonat dibagi menjadi tiga jenis yaitu Tepung Kalsium Karbonat hasil dan penggilingan batu kapur disebut jenis $\mathrm{K}$, tepung hasil penggilingan batu kalsit disebut jenis $\mathrm{C}$ sedangkan jenis $\mathrm{CC}$ adalah tepung calsium hasil dari reaksi dan proses pengendapan. Calcium carbonate juga dapat digunakan untuk bahan pembuatan cat, plastik, kertas, keramik dan masih banyak lagi yang lain (Ullmann's, 1994).

\section{Naftalena, $\mathrm{C}_{10} \mathrm{H}_{8}$}

Naftalena merupakan hidrokarbon siklik yang terdapat dalam ter batu bara yang berbentuk zat padat kristal putih dengan bau yang menusuk, digunakan dalam pembuatan zat celup organik (Ullmann's, 1994). Sebagai senyawa aromatik, struktur Naftalena terdiri dari sepasang gugus arena atau cincin benzena yang bersatu. Naftalena dikenal sebagai bahan utama penyusun kapur barus tradisional. Naftalena memiliki tiga struktur resonasi sehingga elektron dalam gugus arena dalam cicin benzena dapat bergerak bebas seperti sebuah lautan elektron dan menyebabkan ikatan rangkap pada cincin benzena naftalena tidak pasti. Ikatan konjugasi pada Naftalena menyebabkan Naftalena memiliki ikatan tidak jenuh dan memiliki titk leleh $\left(80.26^{\circ} \mathrm{C}\right)$ dan titik didih $\left(218^{\circ} \mathrm{C}\right)$ yang relatif rendah. Dan sifatnya volatil dalam suhu ruangan selain itu Naftalena ditetapkan sebagai karsinogen oleh International Agency for Cancer Research. Naftalena juga diklasifikasikan sebagai polutan yang disebut Polycyclic aromatic hydrocarbons (PAH). (Anonymous, Naftalena, 2013). Gambar 1 menunjukkan rumus bangun naftalena.

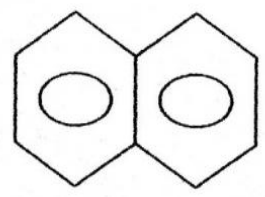

Gambar 1. Rumus Bangun Naphtalena

Untuk menghasilkan beta naphtol dari Naftalena tidak bisa dilakukan reaksi langsung antara Naftalena dengan $\mathrm{NaOH}$, Naftalena harus direaksikan dahulu dengan asam sulfat.

\section{Natrium Karbonat, $\mathrm{Na}_{2} \mathrm{CO}_{3}$}

Natrium karbonat yang sering disebut juga soda abu adalah senyawa sodium yang berbentuk powder, bongkahan berwarna putih keabu-abuan dan mudah larut dalam air serta tidak larut dalam alkohol, titik lebur senyawa tersebut pada suhu $851{ }^{\circ} \mathrm{C}$. Kegunaan dan senyawa tersebut antara lain sebagai bahan baku gelas, pulp dan kertas, industri sabun dan detergen dan masih banyak lagi (Ullmann's, 1994).

\section{Natrium Hidroksida, $\mathrm{NaOH}$}

Natrium hidroksida sering juga disebut caustic soda/soda api, merupakan caustic komersil yang kegunaanya sangat penting sebagai bahan baku atau bahan pembantu pada industri kimia yang terdahulu.

Caustic soda jika dilihat bentuknya ada dua macam yaitu berbentuk butiran padat berwarna putih, biasanya mempunyai kadar yang mendekati $100 \%$ dan dalam bentuk larutan mempunyai kadar yang lebih bervariasi yaitu $40 \%, 50 \%, 72 \%$. Sifat senyawa ini mudah menyerap air dan carbon dioxide dari udara, larut dalam air, alkohol dan gliserol dan juga bersifat basa. Padatan caustic soda mempunyai titik 318 ${ }^{\circ} \mathrm{C}$ sedangkan titik didihnya $1350{ }^{\circ} \mathrm{C}$ (Ullmann's, 1994).

\section{$\beta$-Naftol, $\mathrm{C}_{10} \mathrm{H}_{7} \mathrm{OH}$}

Zat warna $\beta$-naftol berupa kristal tak berwarna yang mempunyai titik leleh 121 $123{ }^{\circ} \mathrm{C}$ dan titik didih $285-286{ }^{\circ} \mathrm{C}$ serta titik nyala $161{ }^{\circ} \mathrm{C}$ dan tidak larut dalam air, sehingga untuk melarutkannya perlu ditambahkan kaustik soda panas $(\mathrm{NaOH})$. Larutan $\beta$-naftol yang terjadi berupa larutan yang jernih dan berwarna kuning. $\beta$-naftol juga dapat digunakan sebagai zat pembawa pada proses pemisahan ion logam dari larutan sisa yang disebabkan oleh aktivitas manusia ataupun industri dengan menggunakan teknologi membran cair. Gambar 2 menunjukkan rumus bangun $\beta$-Naftol 


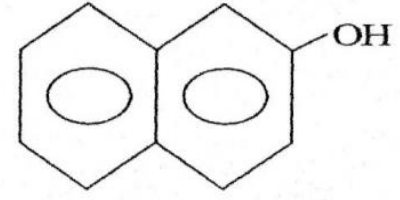

Gambar 2. Rumus bangun $\beta$-Naftol

\section{METODE PENELITIAN}

Proses pembuatan $\beta$-naftol melalui beberapa tahapan proses, yaitu: penimbangan, pemanasan, pencampuran, pengenceran, pengendapan dan penyaringan.

- Persiapan Pembuatan sodium naftalena sulfat

1) Panaskan $0.5 \mathrm{M} \quad \mathrm{H}_{2} \mathrm{SO}_{4}$ di dalam beaker glass dengan suhu $100^{\circ} \mathrm{C}$.

2) lalu tambahkan Naftalena kemudian panaskan hingga suhu mencapai $170^{\circ} \mathrm{C}$ dan ditambahkan soda abu ke dalam beaker glass sedikit demi sedikit.

3) Pemanasan tetap dilakukan hingga suhu mencapai $170^{\circ} \mathrm{C}$, kemudian

4) Diamkan agar dingin lalu ditambahkan larutan lime ke dalam beaker glass.

5) Maka akan didapat kristal sodium naftalena sulfat.

- Persiapan pembuatan $\beta$-naftol.

1) Tambahkan $\mathrm{NaOH}(0,25 ; 0,5 ; 0,75$; $1 ; 1,25 ; 1,5) \mathrm{M}$ pada kristal sodium naftalena sulfat tadi.

2) Lalu panaskan hingga mencapai $300^{\circ} \mathrm{C}$ setelah mencapai suhu tersebut didiamkan hingga dingin.

3) Setelah itu bagian yang telah dingin tadi diencerkan lagi dengan air panas.

4) Teteskan cairan $\mathrm{HCl}$ pekat berlebih kedalam larutan tadi maka akan terbentuk endapan kristal $\beta$-naftol.

\section{Metode Analisis}

Penelitian ini dilakukan untuk mencari Rendemen $\beta$-naphtol dari Naphtalena dengan menggunakan rumus:

$$
\text { Rendemen }=\frac{\mathrm{C}}{\mathrm{X}}
$$

dengan: $X=$ Berat bahan baku (Naftalena)

$C=$ Berat produk ( $\beta$-naftol)

\section{HASIL DAN PEMBAHASAN}

\section{Pengaruh konsentrasi $\mathrm{NaOH}$ terhadap rendemen $\beta$ - Naftol}

Variable konsentrasi natrium hidroksida (mol) yang digunakan dalam pembuatan $\beta$ - Naftol adalah 0,$25 ; 0,50 ; 0,75 ; 1,00$; 1,$25 ; 1,50$. Hasil penelitian dapat dilihat pada Tabel 4.

Tabel 4. Data pengaruh konsentrasi $\mathrm{NaOH}$ terhadap Rendemen $\beta$-naphtol.

\begin{tabular}{ccc}
\hline No. & $\begin{array}{c}\text { Variable } \\
\text { Konsentrasi NaOH } \\
(\mathrm{mol})\end{array}$ & $\begin{array}{c}\text { Rendemen } \\
\beta \text {-naftol }(\%)\end{array}$ \\
\hline 1 & 0,25 & 82,71 \\
\hline 2 & 0,50 & 86,94 \\
\hline 3 & 0,75 & 90,01 \\
\hline 4 & 1,00 & 94,49 \\
\hline 5 & 1,25 & 95,52 \\
\hline 6 & 1,50 & 94,12 \\
\hline
\end{tabular}

Tabel 4 menunjukkan semakin tinggi konsentrasi natrium hidroksida yang digunakan untuk pembuatan $\beta$-naftol semakin banyak pula hasil yang didapat, ini menunjukan bahwa pada reaksi ini konsentrasi natrium hidroksida bebanding lurus dengan hasil yang didapat. Tetapi pada konsentrasi $1,5 \mathrm{~mol}$ natrium hidroksida mengalami kejenuhan. Semakin besar konsentrasi Natrium Hidroksida, maka semakin besar pula hasil yang didapat, ini menunjukan bahwa pada proses pembuatan $\beta$-naftol terjadi hasil yang berbanding lurus antara natrium hidroksida dengan $\beta$-naftol seperti terdapat pada gambar 3 .

\section{Perhitungan Statistik}

Dari data penelitihan didapat hubungan antara konsentrasi natrium hidroksida (X) dengan rendemen $\beta$-naftol (Y), dapat dinyatakan dengan persamaan:

$$
\begin{aligned}
Y= & 9,9737 X+81,905 \\
& \text { dengan } R^{2}=0,8519
\end{aligned}
$$

dengan:

$Y=$ Rendemen $\beta$-naftol dari Naftalena

$X=$ Variabel konsentrasi natrium hidroksida 
Persamaan di atas dapat dilihat pada Gambar 3. dan berlaku untuk konsentrasi natrium hidroksida mulai dari $0,25 \mathrm{~mol}$ sampai $1,50 \mathrm{~mol}$ dengan diperoleh rendemen $90,63 \%$.

Maka dapat disimpulkan ada keterkaitan yang positif antara variabel natrium hidroksida dengan $\beta$-naftol yang didapat selama proses berlangsung karena nilai $R$ $=+1$.

\section{Kadar $\beta$-naftol}

Dari hasil penelitian diperoleh rendemen $\beta$ naftol rata-rata adalah $90,63 \%$, sedangkan menurut literatur rendemen $\beta$-naftol adalah antara $90-96 \%$. Jadi rendemen rata-rata penelitihan ini sudah masuk didalam rentang rendemen $\beta$-naftol menurut 200 Profitable Chemical Industry dan ternyata pada konsentrasi $\mathrm{NaOH} 1,25 \mathrm{~mol}$ diperoleh rendemen sebesar 95,52\%, harga ini mendekati persyaratan yang telah ditentukan. Dari hasil penelitihan ini dihasilkan kadar Rendemen $\beta$-naftol ratarata adalah $90,63 \%$.

\section{Uji titik leleh}

Pada penelitian ini juga dilakukan uji titik leleh $\beta$-naftol dengan menggunakan alat uji melting point. Titik leleh $\beta$-nftol yang didapat pada pengujian ini sebesar $124,8^{\circ} \mathrm{C}$. Beberapa faktor yang mempengaruhi Rendemen $\beta$-naphtol yang dihasilkan, antara lain Konsentrasi kbahan baku, dimana perbandingan mol bahan baku harus tepat, agar diperoleh rendemen $\beta$-naftol yang optimal; kecepatan reaksi dapat ditingkatkan dengan melakukan pencampuran di dalam bejana tertutup dan berpengaduk, hal ini dilakukan juga untuk mencegah terjadinya proses penyubliman dari naftalen pada waktu dipanaskan.

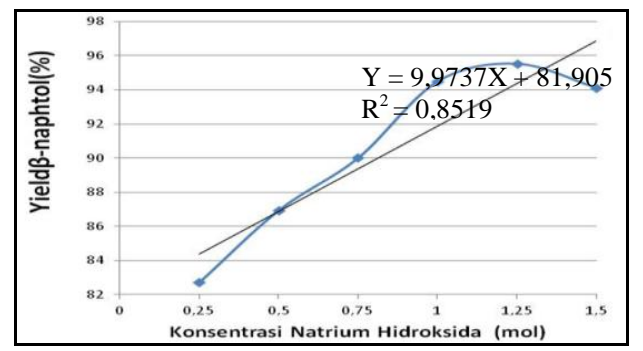

Gambar 3. Hubungan antara Konsentrasi $\mathrm{NaOH}$ (mol) terhadap rendemen $\beta$-Naftol (\%)

\section{KESIMPULAN DAN SARAN}

\section{Kesimpulan}

Dari penelitian ini diketahui bahwa konsentrasi natrium hidroksida dapat mempengaruhi rendemen $\beta$-naftol. Sedangkan konsentrasi $\mathrm{H}_{2} \mathrm{SO}_{4}$ tidak mempengaruhi rendemen $\beta$-naftol._Begitu juga konsentrasi Naftalen tidak mempengaruhi rendemen $\beta$-naftol.

\section{Saran}

Dalam penelitian ini, ada beberapa hal yang perlu diperhatikan, yaitu:

Dianjurkan untuk mengadakan penelitian lebih lanjut terhadap berbagai metode/jenis pembuatan $\beta$-naftol guna mengetahui pewarna celup pada tekstil.

Dianjurkan untuk menggunakan reaktor tangki berpengaduk dan tertutup agar reaksi bisa berjalan dengan sempurna serta untuk mencegah Naftalen menguap pada waktu pemanasan.

\section{DAFTAR PUSTAKA}

Anonymous, 2013, Naftalena, diambil dari https://id.wikipedia.org/wiki/Naftalen a, dilihat Juni 2016.

Lal, Madan, 1993, 200 Profitable Chemical Industri, New Delhi.

Pine, Stainley H., 1996, Kimia Organik, Bandung: Penerbit ITB.

Ullmann's, 1994, Encyclopedia of Chemical Industry, Third Edition, Volume A5, Jhon Willey and Son.

Winarno, F.G., 1997, Kimia Pangan dan Gizi, Jakarta: PT. Gramedia Pustaka Utama. 